\title{
Efektivitas Program Pendampingan Kewirausahaan dan Program Pelatihan Berbasis Partisipatory Training Untuk Mendorong Kemandirian Ekonomi Bagi Komunitas Penyandang Disabilitas di Kabupaten Purbalingga
}

\author{
Weni Novandari ${ }^{1}$, Suliyanto ${ }^{2}$ \\ ${ }^{1}$ Jurusan Manajemen, Fakultas Ekonomi dan Bisnis, Universitas Jenderal Soedirman, Purwokerto, \\ Indonesia \\ 2Jurusan Manajemen, Fakultas Ekonomi dan Bisnis, Universitas Jenderal Soedirman, Purwokerto, \\ Indonesia \\ *Penulis korespondensi, email: weni_novandari@yahoo.co.id
}

\begin{abstract}
situmt:
1 Des 2019

Diterima:

10 Des 2019

Terbit:

20 Des 2019

Abstrak. Populasi penyandang disabililtas di Kabupaten Purbalingga terbilang besar, yaitu mencapai 7.885 orang. Mayoritas para penyandang disabilitas tersebut masuk dalam kategori miskin cacat, yang tinggal di desa dengan kemampuan ekonomi kurang Oleh karena itu, dibutuhkan pendampingan dan pemberdayaan bagi kaum disabilitas ini agar mereka memiliki kemandirian dan berdaya secara ekonomi sehingga dapat mengurangi jumlah masyarakat miskin di Kabupaten Purbalingga. Kegiatan PPM ini bertujuan untuk menguatkan mental kewirausaaan para penyandang disabilitas dan membekali para penyandang disabilitas dengan ketrampilan yang dapat mereka manfaatkan agar mereka dapat mandiri dan berdaya secara ekonomi. Metode pelaksanaan kegiatan adalah 1) Memberikan pelatihan pembuatan produk kerajinan dari kayu, 2) Memberikan bantuan alat produksi, berupa mesin scroll saw,mesin gerenda dan mesin bor. 3) Memberikan penyuluhan dengan materi penguatan mental kewirausahaan. Hasil pelatihan menunjukkan bahwa materi pelatihan yang diberikan sudah sesuai dengan kebutuhan dan kondisi fisik mitra. Dengan pendampingan, diharapkan peserta dapat mempraktikkan ketrampilan yang mereka peroleh dalam kegiatan pelatihan dan memulai usaha untuk membuat dan memasarkan berbagai produk dari limbah kayu.
\end{abstract}

Kata Kunci: partisipatory training, disabilitas, kelompok usaha bersama, pemberdayaan ekonomi 


\section{Pendahuluan}

Kabupaten Purbalingga merupakan salah satu kabupaten termiskin di wilayah Provinsi Jawa Tengah. Angka kemiskinan di Kabupaten Purbalingga mencapai 20,53 persen dari total penduduk Kabupaten Purbalingga. Salah satu kelompok masyarakat yang berada dalam pusaran kemiskinan adalah para penyandang disabilitas. Dari data Bapelitbangda Kabupaten Purbalingga diperoleh informasi bahwa terdapat 7.885 penyandang disabilitas di Purbalingga, dengan kategori umur 0-14 tahun sebanyak 662 orang, umur 15-64 tahun sebanyak 5.071 orang dan diatas 65 tahun sebanyak 2.152 orang (http://jateng.tribunnews.com).

Populasi penyandang disabililtas di Kabupaten Purbalingga terbilang besar. Mayoritas para penyandang disabilitas tersebut masuk dalam kategori miskin cacat, yang tinggal di desa dengan kemampuan ekonomi kurang. Lokasi desa yang jauh dari akses sumber ekonomi, membuat para penyandang disabilitas ini lebih sulit untuk memperoleh lapangan pekerjaan.

Untuk mengatasi permasalah tersebut, Pemerintah Kabupaten Purbalingga melalui Dinas Sosial bekerja sama dengan berbagai elemen masyarakat untuk memberdayakan para penyandang disabilitas agar dapat berdaya secara ekonomi. Para penyandang disabilitas dirangkul untuk bergabung dalam Persatuan Penyandang Disabilitas Indonesia (PPDI) Kabupaten Purbalingga untuk memudahkan kegiatan pemberdayaan dan pembinaan. Dalam organisasi tersebut, para penyandang disabilitas diberikan pelatihan untuk memberikan berbagai ketrampilan yang diharapkan dapat dimanfaatkan oleh para penyandang disabilitas untuk melakukan kegiatan ekonomi secara mandiri.
Namun, belum semua kegiatan pelatihan yang diberikan tepat sasaran dan memberikan hasil yang diinginkan. Terdapat dua faktor penghambat utama belum efektifnya kegiatan pelatihan dan pembinaan yang dilakukan, yaitu;

a. Belum terumuskannya jenis pelatihan yang "tepat" dan sesuai dengan kondisi, kemampuan serta minat mitra. Kondisi fisik dan emosi para penyandang disabilitas menuntut suatu pendekatan pelatihan tersendiri, agar pelatihan yang diberikan tepat sasaran.

b. Belum kuatnya mental kewirausahaan mitra. Pemberian ketrampilan melalui pelatihan saja tidak cukup untuk mendorong para penyandang disabilitas untuk memulai usaha mandiri mereka, dibutuhkan pendampingan untuk memberikan dukungan dan motivasi kepada para penyandang disabilitas ini untuk meyakinkan mereka bahwa mereka bisa berwirausaha agar bisa keluar dari lingkaran kesmiskinan yang mereka hadapi saat ini.

Untuk mengatasi masalah tersebut, dibutuhkan pendekatan pelatihan serta pendampingan yang tepat agar tujuan yang diinginkan yaitu penyandang disabilitas yang mandiri dan berdaya secara ekonomi dapat tercapai.

\section{METODE}

Metode pelaksanaan kegiatan pengabdian kepada masyarakat ini adalah pelatihan dengan pendekatan partisipatory training dan pendampingan kewirausahaan.

a. Pendekatan partisipatif dalam pelatihan (partisipatory learning) adalah kegiatan pelatihan yang dibangun atas dasar partisipasi aktif (keikut sertaan) peserta pelatihan dalam semua aspek kegiatan pelatihan, mulai dari kegiatan merencanakan, melaksanakan, sampai pada tahap menilai kegiatan pembelajaran dalam pelatihan. Upaya yang 
dilakukan pelatih pada prinsipnya lebih ditekankan pada motivasi dan melibatkan kegiatan peserta, agar pelatihan yang diberikan benar benar sesuai dengan kebutuhan dan juga minat peserta pelatihan.

b. Pendampingan untuk menguatkan mental kewirausahaan mitra. Pendampingan akan berbentuk penyuluhan dan pemberian motivasi berwirausaha.

\section{HASIL DAN PEMBAHASAN}

Peserta kegiatan PPM adalah anggota Persatuan Penyandang Disabilitas Indonesia (PPDI) Kabupaten Purbalingga. Sebelum kegiatan pelatihan diadakan, dilakukan diskusi dengan peserta, untuk mengidentifikasi pelatihan apa yang mereka inginkan dan produk apa saja yang ingin mereka buat dalam pelatihan. Dari hasil diskusi teridentifikasi bahwa pelatihan yang diinginkan adalah pembuatan berbagai produk dari limbah kayu. Pertimbangan mengapa pelatihan pembuatan produk dari limbah kayu adalah limbah kayu banyak tersedia dan dapat dimanfaatkan serta diolah menjadi berbagai produk yang bernilai ekonomis. Selain itu, proses pembuatan produk kerajinan dari limbah kayu relatif mudah, serta tidak membutuhkan peralatan khusus, ketrampilan khusus atau modal yang besar. Para penyandang disabilitas dapat mengerjakan kegiatan ini di rumah sebagai salah satu sumber pendapatan, dengan berbekal ketekunan, ketelitian dan kreativitas mereka. Selain itu, harga produk juga relatif tidak mahal, sehingga berpotensi untuk cepat terjual.

Jumlah peserta pelatihan adalah 10 orang, yang terdiri dari 7 orang penyandang tunadaksa, serta 3 orang penyandang tunarungu dan tunawicara. Pada pelaksanaan kegiatan pelatihan, peserta dibagi menjadi 3 kelompok, yaitu 4 orang mengikuti pelatihan pembuatan peralatan rumah tangga, 4 orang mengikuti pelatihan pembuatan mainan edukatif untuk anak, dan 2 orang mengikuti pelatihan pembuatan hiasan dinding. Dalam penyampaian materi pelatihan, khususnya kepada para penyandang tunarungu, Tim dibantu oleh ahli bahasa isyarat dari Sekolah Luar Biasa Purbadisuta, Purbalingga. Dalam kegiatan pelatihan, para peserta diberi kebebasan penuh untuk membuat desain produk yang mereka sukai. Pelatih hanya memberikan dasar dasar, memberi petunjuk dan mengarahkan peserta dalam proses pelatihan. Hal ini disengaja oleh Pelatih, untuk memaksa peserta pelatihan agar dapat melogika-kan tahapan pembuatan produk kerajinan dari limbah kayu dan melatih kreativitas dari para peserta.

Untuk menilai efektivitas pelaksanaan kegiatan pelatihan yang diberikan, Tim melakukan evaluasi terhadap beberapa komponen pelatihan, meliputi; kesesuaian materi pelatihan dengan kebutuhan peserta, kesesuaian materi pelatihan dengan minat peserta, dan kesesuaian materi pelatihan dengan kondisi fiksik mitra.

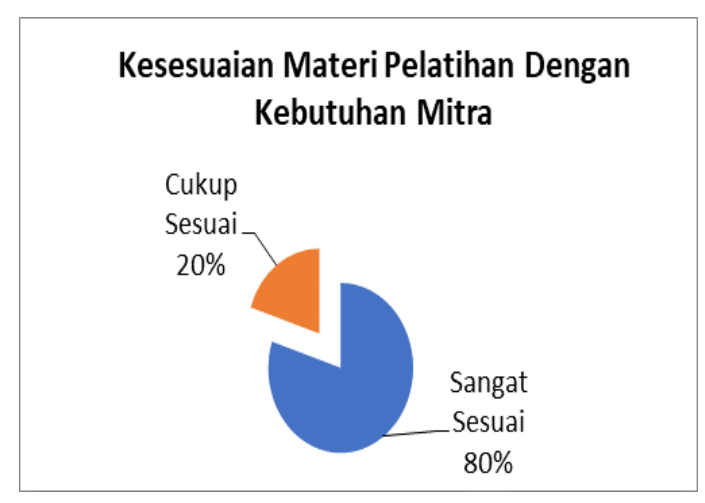

Gambar 1. Kesesuaian materi pelatihan dengan kebutuhan mitra 


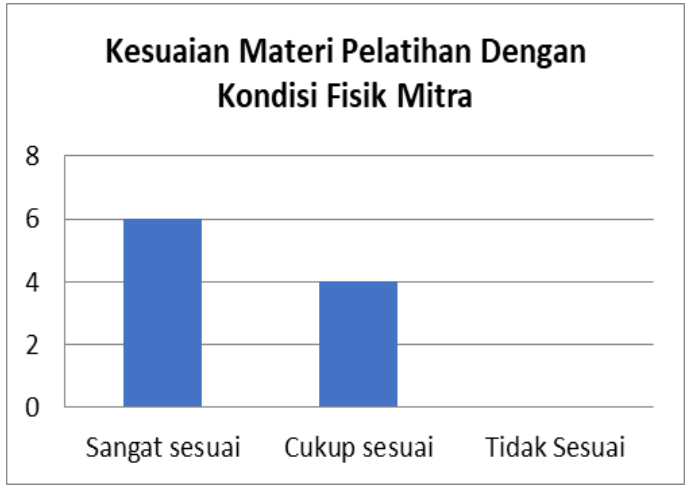

Gambar 2. Kesesuaian materi pelatihan dengan kondisi fisik mitra

Gambar 1 menunjukkan bahwa $80 \%$ peserta menyatakan bahwa materi pelatihan sudah sesuai dengan kebutuhan mereka. Yang diiinginkan peserta adalah mereka dapat menguasai ketrampilan pembuatan produk yang sederhana serta mudah dibuat, tiak membutuhkan modal besar untuk memulai usaha dari ketrampilan yang diberikan, serta produk mudah dipasarkan sehingga mereka dapat segera memperoleh uang dan modal dapat terus berputar. Produk peralatan rumah tangga, seperti talenan, rak dapur serta permainan edukatif, seperti puzzle, relatif mudah untuk dikuasai, meskipun pengetahuan pembuatan berbagai produk dari kayu limbah belum pernah mereka peroleh sebelumnya. Setelah pelatihan untuk mempraktikkan kembali ketrampilan yang mereka perolah dari pelatihan juga relatif mudah dan murah. Dengan berbekal limbah kayu yang tersedia melimpah di sekitar mereka serta ketrampilan yang diberikan dari pelatihan, peserta pelatihan terdorong untuk dapat memulai usaha pembuatan produk dari kayu meskipun masih dalam skala yang sangat terbatas.

Gambar 2 menunjukkan bahwa materi yang diberikan sudah sesuai dengan kondisi fisik mitra. 7 peserta pelatihan merupakan penyandang tunadaksa, yang memiliki keterbatasan fungsi tangan dan kaki. Dalam pembuatan produk dari kayu, alat alat yang digunakan seperti mesin jig saw dan mesin bor relatif sangat sederhana, dan mudah untuk dioperasikan. Namun masih terdapat satu peserta yang kesulitan untuk mengoperasikan mesin tersebut. 3 peserta pelatihan merupakan penyandang tunarungu. Kinerja pelatihan para penyandang tunarungu sangat baik. Mereka mudah untuk menguasai materi pelatihan, memiliki kreativitas tinggi, dan bersemangat mengikuti pelatihan yang diberikan. Selain itu, peserta tunarungu juga sangat fokus dan tekun dalam mengikuti pelatihan.

Setelah kegiatan pelatihan, para peserta mendapatkan pendampingan dari Tim dan Yayasan Pilar Purbalingga. Selain pelatihan, Tim juga memberikan bantuan alat produksi berupa mesin jigsaw, mesin bor dan modal kerja berupa kayu limbah, yang semuanya ditempatkan di Sekretariat PPDI Purbalingga. Para anggota PPDI Purbalingga dapat terus mengasah ketrampilan mereka dalam kegiatan pertemuan anggota PPDI yang diadakan secara rutin sekali dalam sebulan. Produk produk yang dihasilkan, dipasarkan oleh Yayasan Pilar Purbalingga melalui beberapa even pameran yang diadakan di Kabupaten Purbalingga.

\section{KESIMPULAN}

Seluruh kegiatan yang direncanakan berjalan dengan baik dan lancar. Peserta antusias dalam mengikuti pelatihan yang diberikan. Setelah kegiatan pelatihan, peserta mempraktikkan hasil pelatihan dengan pendampingan dari Yayasan Pilar Purbalingga. Dengan menggunakan bahan baku limbah kayu yang diberikan, peserta terus mengasah ketrampilan mereka dalam membuat berbagai produk. Kegiatan pengabdian masih terus dilanjutkan dengan memberikan pendampingan kepada peserta. Fokus dalam kegiatan pendampingan adalah meningkatkan kualitas produk kerajinan yang dibuat (diantaranya presisi atau ketepatan ukuran, kehalusan permukaan produk, dan kualitas pewarnaan 
kayu). Selain itu, peserta juga didorong untuk meningkatkan kreatifitas dalam pembuatan berbagai macam produk kerajinan dan alat alat rumah tangga.

\section{Ucapan Terimakasih}

LPPM Universitas Jenderal Soedirman, Yayasan Pilar Purbalingga.

DAFTAR PUSTAKA

http://jateng.tribunnews.com 